\title{
Total kalça artroplastisinde mekanik artsorunlar
}

\author{
Mechanical complications in total hip arthroplasty
}

\author{
Faik Altıntaş, Çağatay Uluçay, Turhan Özler
}

Yeditepe Üniversitesi Tıp Fakültesi, Ortopedi ve Travmatoloji Anabilim Dalı, İstanbul

\begin{abstract}
Total kalça ameliyatı, ülkemizde ortopedik cerrahların en sık yaptığı ameliyatlardan biridir. Ameliyat sonrası gelişen artsorunlar genel olarak başarı oranını olumsuz etkiler. Enfeksiyon, derin ven trombozu ve mekanik artsorunlar, hasta memnuniyetini etkileyen sorunların başında gelmektedir. Bu derlemede, periprostetik kırıklar, heterotopik ossifikasyon, implant başarısızlığı, nörovasküler artsorunlar ve instabiliteyle ilgili tanı ve tedavi stratejileri ile güncel yaklaşımlar anlatılmaktadır. Genel olarak mekanik artsorunların tedavisi, öncelikle oluşmasının engellenmesi, eğer engellenemedi ise müdahale öncesi, nedenin ve çözüm algoritmalarının iyi bilinmesini gerektirir. Bu kurallara uyulursa, gelişmiş olan artsorunların büyük bir kısmı başarıyla tedavi edilir.
\end{abstract}

Anahtar sözcülkler: total kalça replasmanı; protez çevresi kırıklar; komplikasyonlar; mekanik kavramlar
Total hip arthroplasty operation is one of the most common surgical procedures practiced by orthopaedic surgeons in our country. Postoperative complications have a negative influence on the success rate of the procedure in general. The main factors that determine the postoperative satisfaction of the patient are infection, deep venous thrombosis, and mechanical complications. In this review, current diagnosis and treatment algorithms for periprosthetic fractures, heterotopic ossification, implant failure, neurovascular complications, and instability are explained. Generally, the treatment of mechanical complications starts by taking preventive measures; and if they are inevitable, the cause and treatment algorithm of these complications had to be learned meticulously before intervening. Proper handling of these factors lead to successful results in most of the cases.

Key words: total hip replacement; periprosthetic fractures; complications; mechanical concepts

\section{PERIPROSTETIK KIRIKLAR}

Total kalça protezi (TKP) sonrası gelişen protez çevresi kırıklar ve bu kırıkların tedavi seçenekleri uzun yıllardır ortopedistleri zorlar. ${ }^{[1]}$ Yıllar içerisinde, çimentolu asetabuler komponentin daha az uygulanmasından dolayı, ameliyat içi periasetabuler kırıklar çok nadir görülse de, çimentosuz asetabulum uygulamalarında ameliyat içi kırık riski halen mevcuttur. ${ }^{[2]}$ Ameliyat sonrası periasetabuler kırıklar femur kırıklarına göre daha nadirdir. ${ }^{[3]}$ Ameliyat içi femur kırığı ise, çimentolu uygulamalarda \%0,3 gibi nadiren görülürken, çimentosuz uygulamalarda $\% 5,4$ ve hatta revizyon uygulamalarında $\% 30$ sıklıkla görülebilir. ${ }^{[3,4]}$

Ameliyat içi kırık nedenleri arasında ileri osteoporotik kemik, primer stabilite için gereksiz büyük boyutlu komponent çakılması, patolojik kırık varlığında TKP

ameliyatı yapılması ve özellikle proksimal femurun kullanılan femoral komponent ile uyumsuzluğunun fark edilememesi sayılabilir. Özellikle, proksimal tutulumlu femoral komponent kullanımında metafizer, tam poroz kaplı komponent kullanımında diyafizer femur kırıkları daha sık görülür. ${ }^{[5]}$

Ameliyat içi tanı şüphe ile başlar. Zorlanarak çakılan bir komponentin aniden daha kolay çakılmaya başlaması veya stabil olacağını düşündüğünüz bir komponentte çakma sonrası gevşeme görülmesi, aksi ispatlanana dek periprostetik kırıktır. Her hastada komponentlerin uygulanması sonrası cerrahi sahanın yıkanıp temizlenmesi ile özellikle asetabuler duvarlarda ve femur boynunda herhangi bir kırık veya fissür olup olmadığı kontrol edilmelidir. Ameliyat sonrası ani başlangıçlı ağrı, travma olsun veya olmasın akla periprostetik kırık intimalini getirmelidir. Tanıda direkt grafi (özellikle eski direkt grafilerle karşılaştırmalı

- İletişim adresi: Dr. Çağatay Uluçay, Yeditepe Üniversitesi Tıp Fakültesi, Ortopedi ve Travmatoloji Anabilim Dalı, Devlet Yolu Ankara Cad. No 102, 34578 Kozyatağı, İstanbul Tel: 0532 - 7284719 e-posta: culucay@tnn.net

- Geliș tarihi: 28 Mart 2013 Kabul tarihi: 9 Temmuz 2013 
Tablo 1. Asetabuler periprostetik kırıklarda Peterson sınıflaması ${ }^{[2]}$

\begin{tabular}{ll}
\hline Tip 1 & Stabil asetabuler komponent \\
Tip 2 & Instabil asetabuler komponent
\end{tabular}

çekilen), bilgisayarlı tomografi ve nadir durumlarda pozitron emisyon tomografi - bilgisayarlı tomografi (PET-CT) ve manyetik rezonans görüntüleme (MRG) kullanılır.

Periprostetik kırık varlığında tedavide iki önemli belirleyici vardır: 1) Komponentin kırık sonrası stabilitesi 2) Kırığın yeri ve şekli.

Periasetabuler kırıklar genel olarak Letournel sınıflamasına göre kırığın yeri ve şekli ile sınıflandırılır. ${ }^{[6]}$ Daha kolay olan bir sınıflama ise Peterson sınıflamasıdır. ${ }^{[2]}$ Tip 1 stabil komponent, Tip 2 instabil komponent varlığını gösterir (Tablo 1 ).

Tip 1 kırığın tedavisi 6-12 hafta arası yük vermemek ve aylık röntgen kontrolünü kapsarken, Tip 2 kırıklarda tedavi yeterli primer stabilitenin sağlanmasıdır. Bunun için vidalı asetabuler komponent kullanımı, serbest vida, vida-plak kombinasyonları, allogreft kullanımı ve hatta pelvik devamsızlık varlığında asetabuler kafes ile birlikte çimentolu komponent kullanımı gerekebilir. ${ }^{[3]}$ Ameliyat içi sağlanan stabiliteye göre hastaya ameliyat sonrası kısmi yük verdirilir.

Femur kırıklarda ise, Vancouver sınıflaması kullanılır. [7] Sonuç üzerinde önemli belirleyici olan üç ayrı faktör üzerinden sınıflama yapılmıştır. Bunlar, kırı̆ıın yeri, femoral sapın stabilitesi ve kemiğin kalitesidir. Bu sınıflama daha sonra ameliyat içi kullanımın da sağlanabilmesi için modifiye edilmiştir. ${ }^{[8]}$ Bu kırıkların tedavisi tiplere ve ameliyat içi/sonrası oluşumuna göre değiş̧mektedir (Tablo 2).

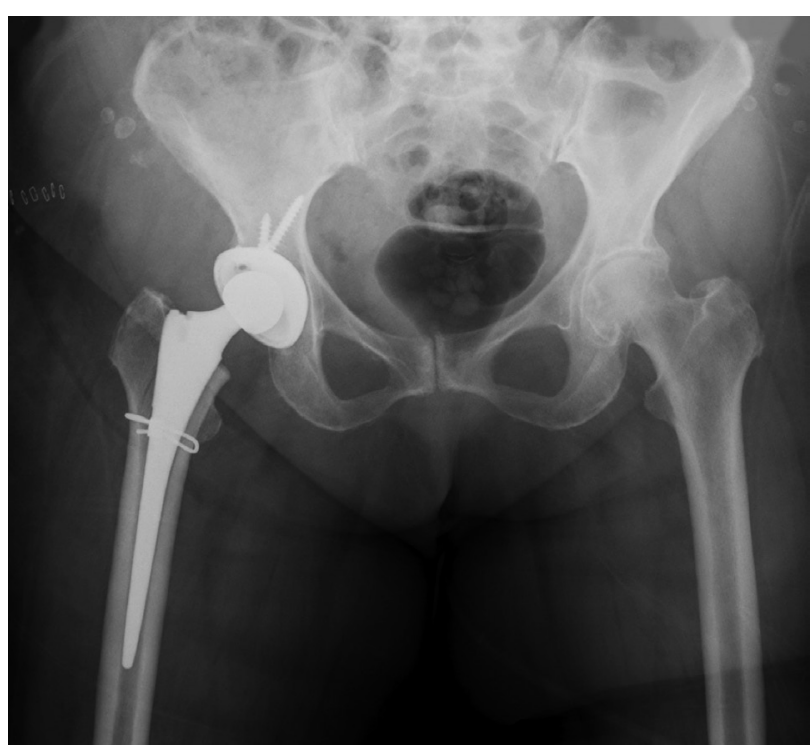

Şekil 1. Tip A 2 periprostetik femur kırığının kablo ile ameliyat içi tedavisi.

\section{Tip A kırıkların tedavisi}

Ameliyat içi olan A g 1 ve A I 1 kırıklar genel olarak sapın stabilitesini etkilemediği için ek tedaviye ihtiyaç duymaz. A 2 kırıklarda ise genellikle sapın çakılması öncesi serklaj veya kablo ile sıkıştırma, hem kırığın ilerlemesini hem de çakma esnasında tip A 3'e dönüşmeyi engelleyecektir (Şekil 1). A 3 kırıklarda eğer kalkar bölgesi etkilendi ise diafizer tutulumlu tam poroz kaplı bir komponent yerleştirmek gereklidir. Tip A g 3 kırıklarda ise abduktor kol zaafiyetini engellemek için trokanterik grip ve kablo sistemlerinin kullanılması önerilir. Özellikle ek tedavi uygulanmamış A g 1 ve 2 tipi kırıklarla ameliyat sonrası trokanter majörün ayrışma ihtimaline karşı yakın takip ve aktivite kısıtlaması önerilir.

Tablo 2. Periprostetik femur kırıklarında Vancouver sınıflaması ${ }^{[7]}$ ve ameliyat içi kullanımının modifikasyonu ${ }^{[8]}$

\begin{tabular}{|c|c|c|c|}
\hline Tip & Kırığın yeri & Alt grup & Ameliyat içi oluşan kırığın tipi \\
\hline A & Pertrokanterik & $\begin{array}{l}\text { A g: Büyük trokanter } \\
\text { A I: Küçük trokanter }\end{array}$ & $\begin{array}{l}\text { 1. Basit kortikal perforasyon } \\
\text { 2. Ayrışmamış çizgisel kırık } \\
\text { 3. Ayrışmış veya instabil kırık }\end{array}$ \\
\hline B & Sapın çevresi veya ucu & $\begin{array}{l}\text { B 1: Protez stabil } \\
\text { B 2: Protez instabil ama yeterli kemik stoğu mevcut } \\
\text { B 3: Hem protez instabil hem de kemikte ileri } \\
\text { osteoliz ve/veya yetersiz kemik stoğu mevcut }\end{array}$ & $\begin{array}{l}\text { 1. Basit kortikal perforasyon } \\
\text { 2. Ayrışmamış çizgisel kırık } \\
\text { 3. Ayrışmış veya instabil kırık }\end{array}$ \\
\hline C & Saptan aşağı & & $\begin{array}{l}\text { 1. Basit kortikal perforasyon } \\
\text { 2. Ayrışmamış çizgisel kırık } \\
\text { 3. Ayrışmış veya instabil kırık }\end{array}$ \\
\hline
\end{tabular}




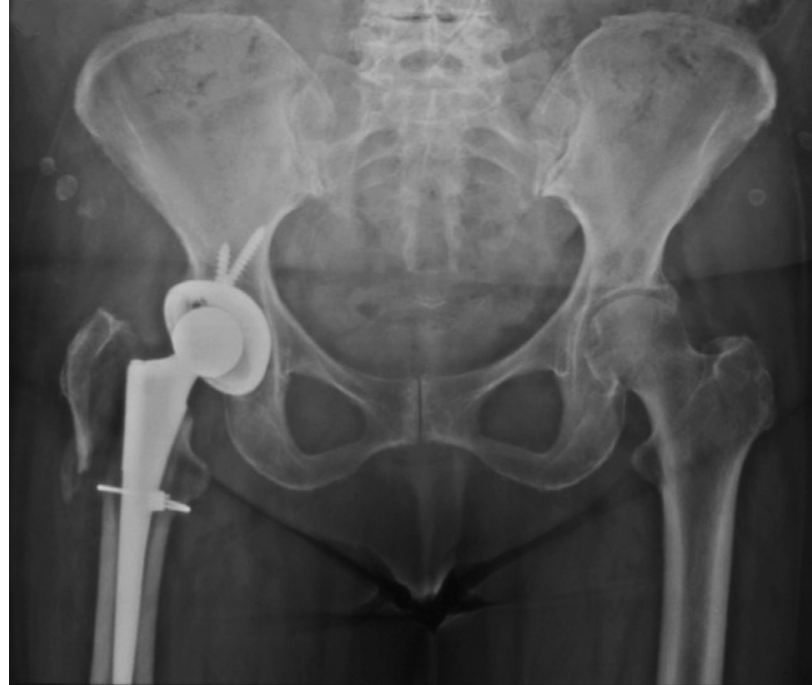

Şekil 2. Tip A g periprostetik femur kırı̆̆ı.

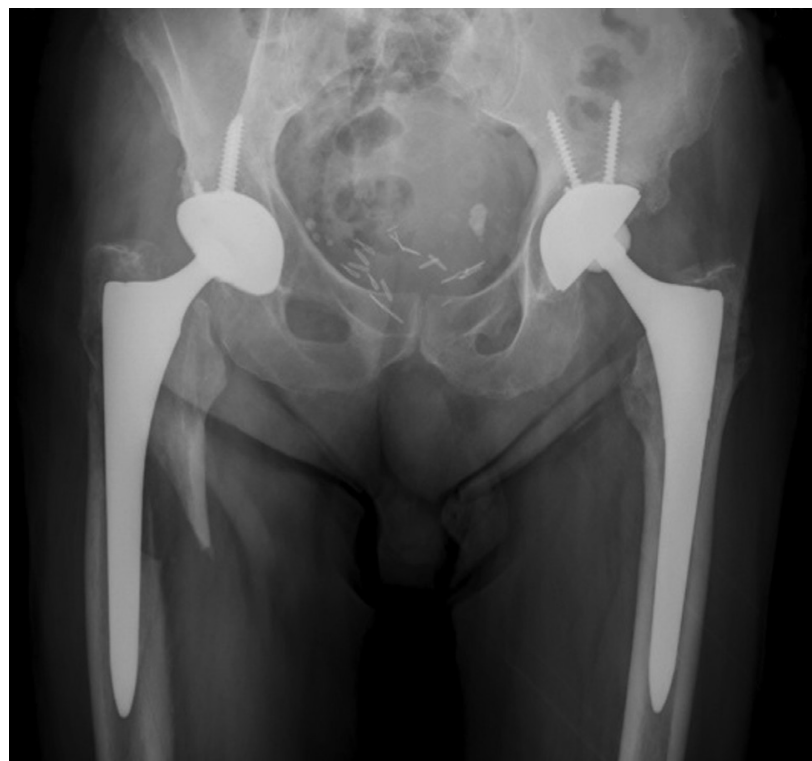

Şekil 4. Tip A I periprostetik femur kırığı.

Ameliyat sonrası olan tip A kırıklar genellikle cerrahi tedaviye ihtiyaç duymaz. Tip A g kırıkta $2 \mathrm{~cm}$ 'den az deplasman varsa genellikle kısmi yük verme, adduksiyonu kısıtlama veya kalça abduksiyon cihazı kullanımı ile 6-12 hafta arası yeterli kaynama sağlanır. Eğer deplasman miktarı $2 \mathrm{~cm}$ 'den fazla ise veya verilmiş konservatif tedaviye rağmen ağrılı kaynamama, aşırı topallama veya kalça instabilitesi varsa hasta cerrahi olarak tedavi edilir. Bu tedavi için en sık trokanterik grip kablo sistemi kullanılır (Şekil 2 ve 3). Tip A I kırıklar nadir olarak görülür ve konservatif olarak tedavi edilir. Eğer trokanter minör kalkardan büyük bir parça

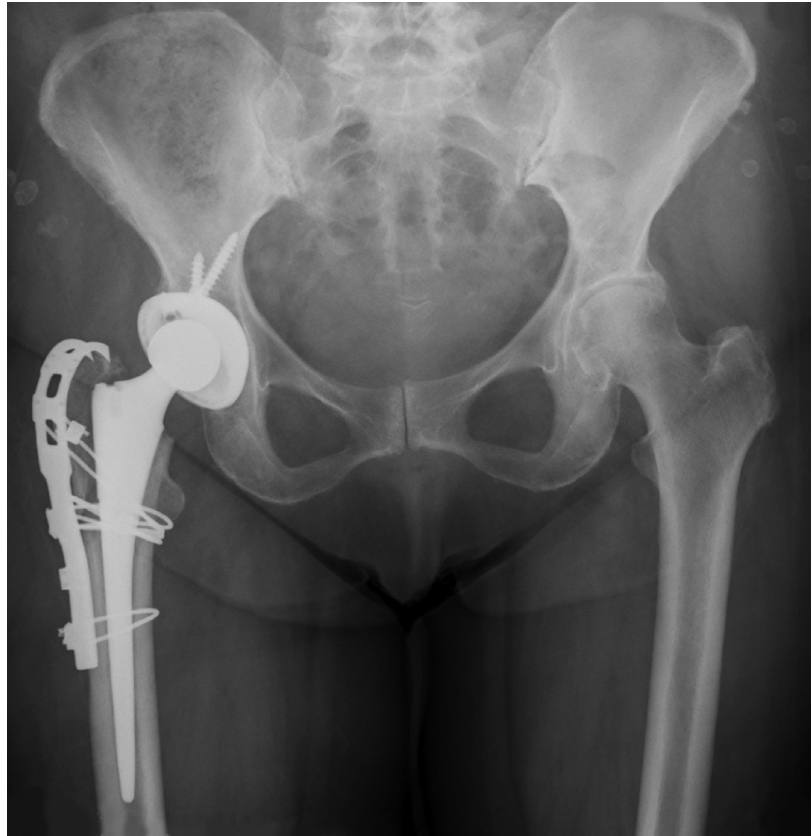

Şekil 3. Trokanterik grip kablo sistemi ile kırığın tespiti.

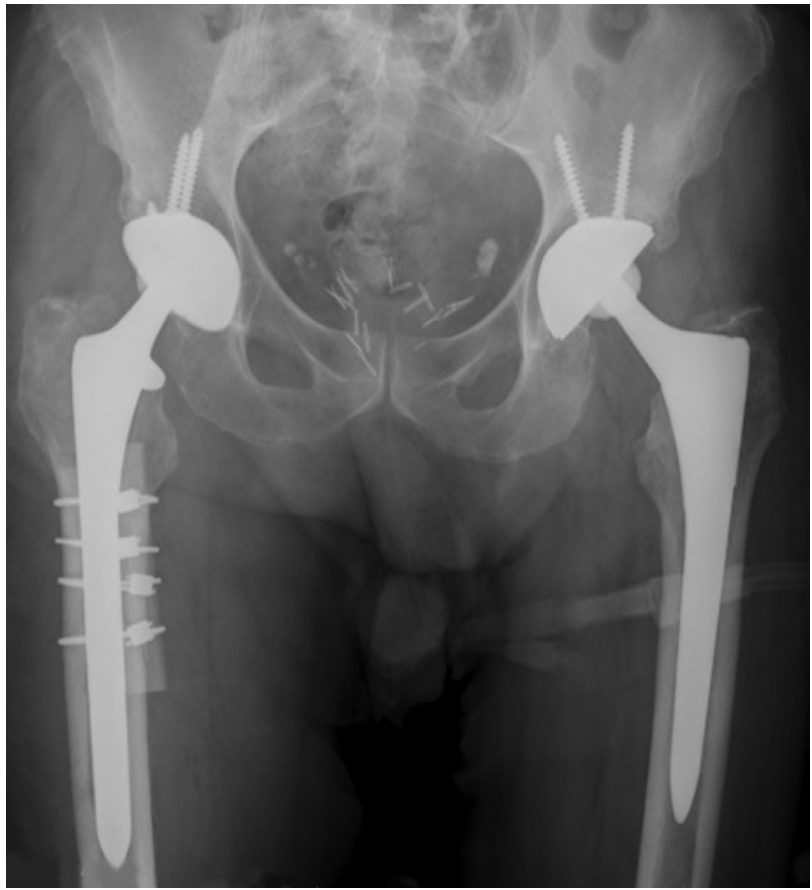

Şekil 5. Femoral komponent revizyonu ile birlikte, kablo grip sistemi ve yapısal allogreft kombinasyonuyla kırığın tespiti.

kopartarak ayrılmış ise veya konservatif tedaviye rağmen kalça fleksiyonu yetersiz ise cerrahi tedavi yapılır. Tedavide eğer sapta proksimal instabilite gelişmiş ise tam poroz saplı bir komponent ile revizyon, instabilite yok ise serklaj veya kablo ile kırı̆gın yerine tespiti yapılır (Şekil 4 ve 5). 


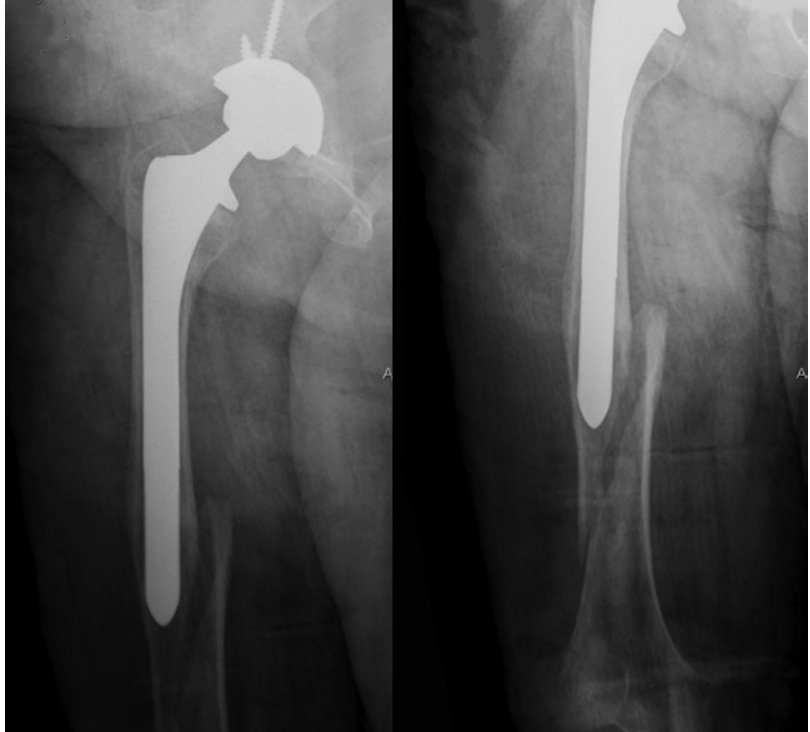

Şekil 6. Tip B I periprostetik femur kırı̆̆ı.

\section{Tip B kırıkların tedavisi}

Ameliyat içi olan B 1 kırıklarda sapın tutulum yüzeyinin, kırık sahasının bulunduğu bölgenin diafiz çapının en az iki katı uzunlukta olacak şeklide kırığı geçmesi gereklidir. ${ }^{[9]}$ Bu sayede genellikle ek bir tedaviye gerek olmadan stabilite sağlanır. Eğer en uzun sap kullanılmasına rağmen yeterli mesafe sağlanamıyorsa, yapısal allogreft ve kablo/kablo-plak kombinasyonları kullanılabilinir. B 2 kırıklar ise genellikle serklaj veya kablo kullanımı ve uygun boyda tam poroz sapa geçilerek tedavi edilir. Ek olarak kemik kalitesi kötü ise tespit yerine yapısal kortikal greftler eklenerek mevcut kemik kalitesinin arttırılması sağlanır. B 3 kırıklarda eğer kırık tipi oblik veya spiral ise serklaj veya kablo tespiti yeterli iken, transvers kırıklarda en az bir yapısal kortikal greft kaynamayı arttırmak için kullanılmalıdır. Değişik markaların kablo-plak veya kilitli plak-vida kombinasyonları da bu kırıklarda kullanılabilir. Yeterli tespit sonrası uygun boyda tam poroz kaplı sap çakılır.

Ameliyat sonrası olan tip B 1 kırıklarda tedavi kırık stabilizasyon prensiplerine dayanır. Sadece birkaç serklaj veya kablo ile tedavinin yeterli olacağı düşünülmemelidir. Yetersiz tespit yapılması durumunda stabil olan femoral komponent kısa sürede instabil hale gelecek ve hasta erken sürede revizyon ameliyatı ihtiyacı duyacaktır. Genellikle kablo-plak veya kilitli plak-vida kombinasyonları ile tedavi edilir. Genellikle tespite yapısal kortikal allogreft eklenerek, daha erken kaynama ile daha iyi sonuçlar alınır (Şekil 6 ve 7). ${ }^{[10]}$ B 2 kırıklarda ise femoral komponent revize

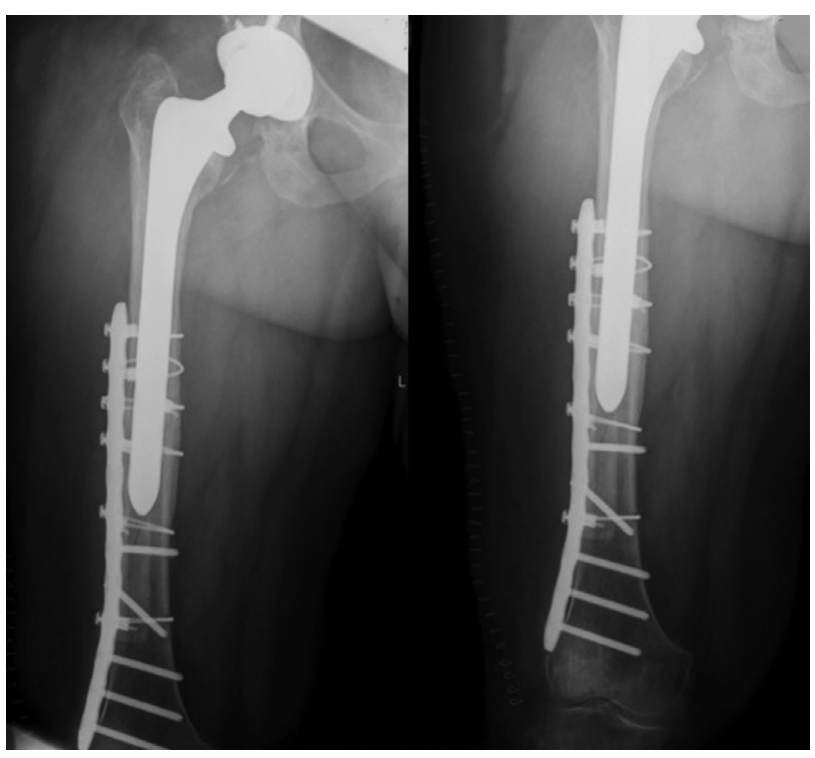

Şekil 7. Kablo-kilitli vida plak ve yapısal allogreft kombinasyonuyla kırığın tespiti.

edilmelidir. Seçilen tam poroz femoral komponentin tutulum yüzeyinin, kırık sahasının bulunduğu bölgenin diafiz çapının en az iki katı uzunlukta olacak şeklide kırı̆̆ geçmesi gereklidir. Distal tutulumlu yeterli uzunlukta bir protezin çakılması sonrası proksimalde kalan kırık parçaların yapısal femoral allogreftlerle kırık hattına kablolar ile sarılması da hem stabiliteye hem de kaynamayı arttırmaya yardımcı olur (Şekil 8 ve 9). Bu kırıklarda femoral komponentin revizyonuna rağmen rotasyonal stabilitenin yetersiz olduğu düşünülürse ek olarak kablo-plak veya kilitli plakvida kombinasyonları da eklenmelidir. Çimentolu bir revizyon planlanıyor ise yine yeterli uzunlukta bir komponent seçilmeli ve genellikle impaksiyon greftleme yapılmalıdır. B 3 kırıklarda ise tedarik edilebilinirse yapısal proksimal femur allogrefti kullanılabilir. ${ }^{[11]}$ Distal tutulumlu yeterli uzunlukta bir protezin çakılması sonrası proksimalde kalan kırık parçaların yapısal femoral allogreftlerle kombine edilerek sapın proksimaline kablolar ile sarılması da bir çözüm yolu olabilir (Şekil 10 ve 11). Bu kırıklarda uygun boyda modüler protezler ve hatta tümör protezlerinin de gerekebileceği unutulmamalıdır. ${ }^{[12]}$

\section{Tip C kırıkların tedavisi}

C 1 kırıklar nadir olarak görülür. Eğer var ise greftleme ve yapısal kortikal greftler ile korteks desteklenerek, bu deliğin ileride oluşturabileceği stres arttırma etkisi engellenmelidir. C 2 kırıklar ise genellikle kablo ve/veya kablo-yapısal greft kombinasyonları ile tedavi edilir. C 3 kırıklarda ise ya femoral komponentin 


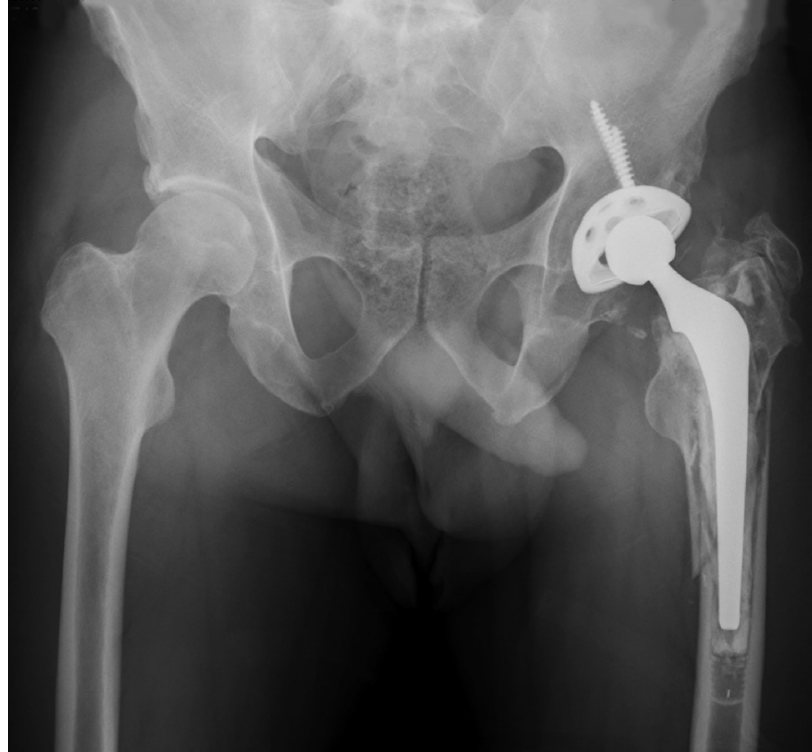

Şekil 8. Tip B 2 periprostetik femur kırığı.

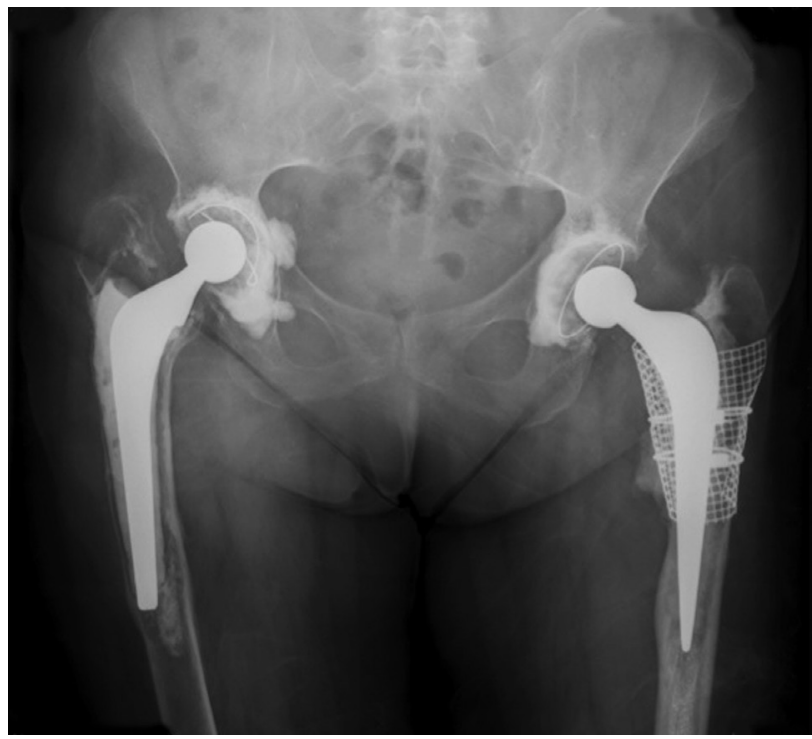

Şekil 10. Tip B 3 periprostetik femur kırığı.

yeterli uzunlukta tam poroz bir komponentle değişimi ya da kırı̆̆ın stabilizasyonu için açık yerleştirme ve içsel tespit, gerekirse primer greftlenmesi gereklidir. Tespitte kablo-plak veya kilitli plak-vida kullanılır. Vida kullanılırken dikkat edilmesi gereken durumlardan biri sapın bulunduğu bölümde tek korteks geçilebilirken, sapın altındaki vidaların çift korteks geçilmesidir. Tek korteks tutulumu yapılan tarafta kablolar ile plağın üzerinden ekstra sabitleme yapılması, kırığın tespit gücünü arttıracaktır. Gerekli görülürse yapısal kortikal greft, kaynamayı arttırıcı ajanlar ve otogreft bu tespitlemeye eklenir.

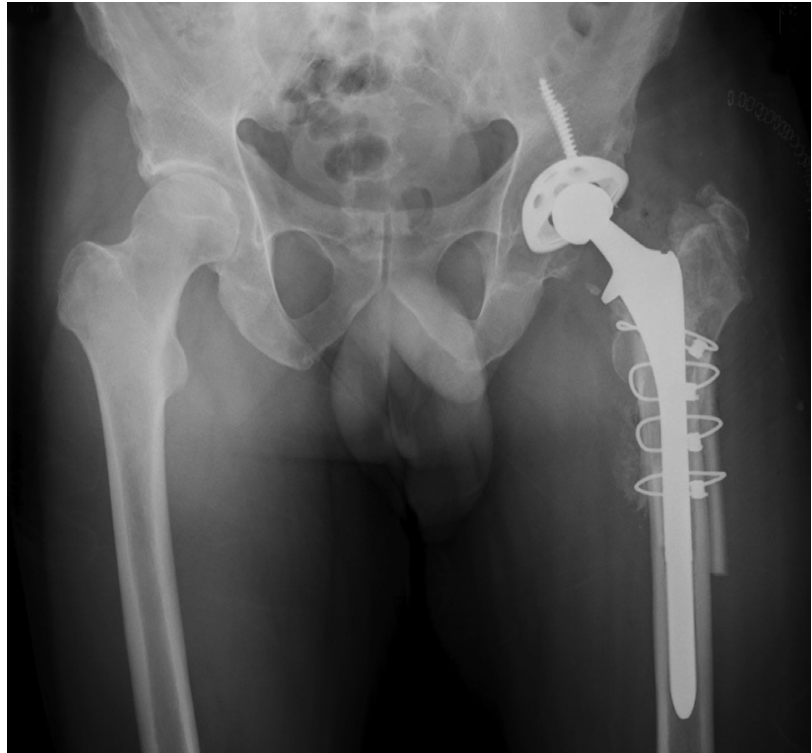

Şekil 9. Femoral komponent revizyonu ile birlikte, kablo grip sistemi ve yapısal allogreft kombinasyonuyla kırı̆̆ın tespiti.

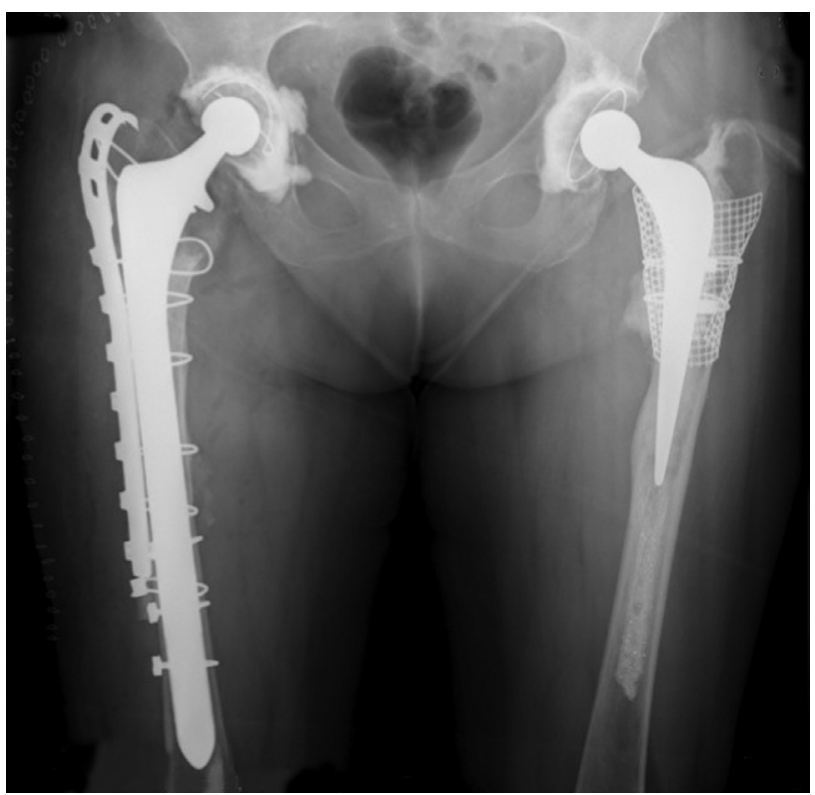

Şekil 11. Femoral komponent revizyonu ile birlikte, uzun trokanterik grip, kablo grip sistemi ve yapısal allogreft kombinasyonuyla kırı̆̆ın tespiti.

Ameliyat sonrası olan tip C kırıklarda femoral komponentin stabilitesi ile ilgili sorun olmadığından, genellikle komponent revizyonu yapılmaz. Tedavi prensipleri aynı ameliyat içi oluşan tip C kırıkları gibidir (Şekil 12 ve 13). Günümüzde genellikle "less invasive stabilization system" (LISS) plakları ile göreceli stabilizasyon prensipleri ile tedavi edilmektedir. 


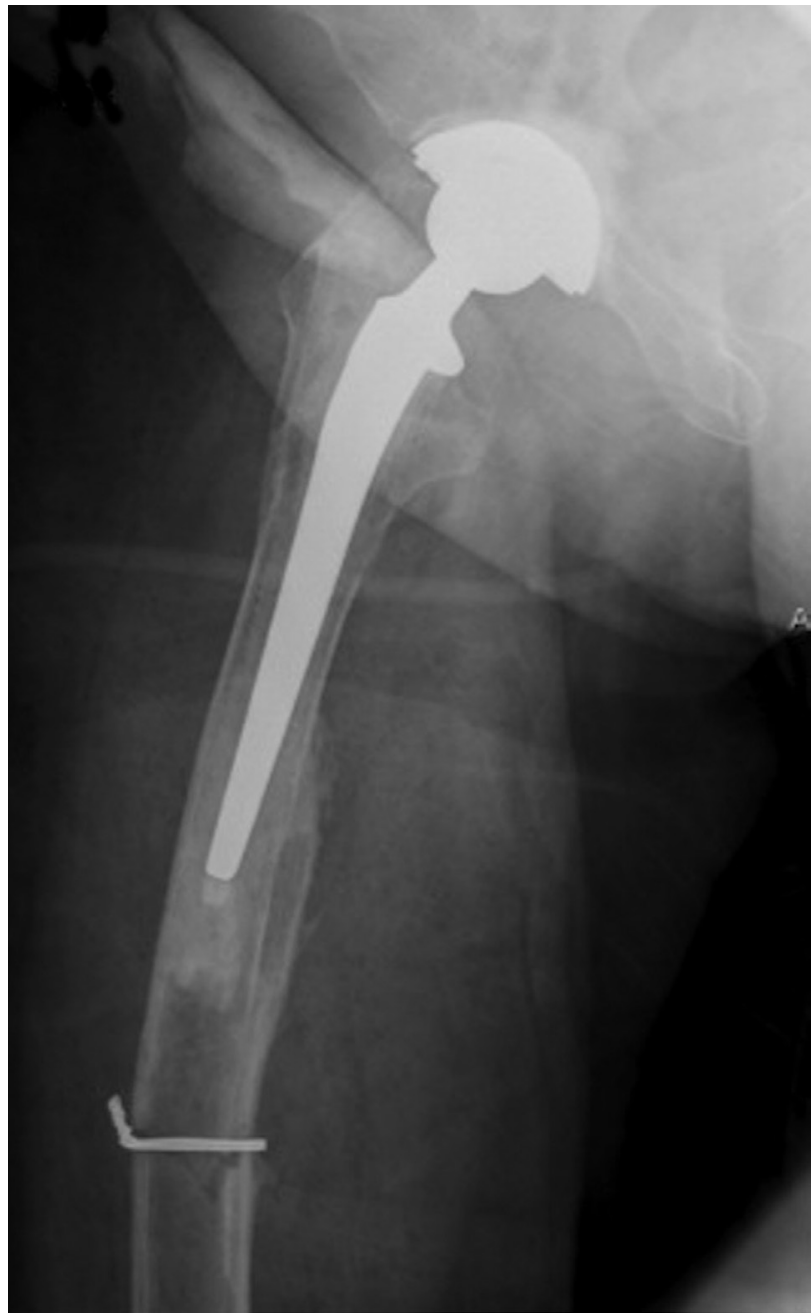

Şekil 12. Tip C periprostetik femur kırı̆̆ı.

Periasetabuler kırıkların tedavi sonuçları tiplendirme ile ilişkilidir. Tip 1'de sonuçlar genel olarak çok başarılı iken, Tip 2'de özellikle pelvik devamsızlık varlığında yüz güldürücü değildir. ${ }^{[2]}$ Asetabulum kırıklarında deneyimi olan travma cerrahları ile ameliyata girilmesi önerilir. Ameliyat öncesi çeşitli rekonstrüksiyon plakları, vidalar, jumbo asetabuler komponent, çimentolu asetabuler komponent, spongioz allogreft ve hatta değişik asetabuler halka ve kafes çeşitlerinin hazır olması önerilir. Femur kırıklarında ise sonuçlar hem cerrahi tekniğe hem de kemik kalitesine göre değişmektedir. Genellikle en kötü sonuçlar B 2 ve 3 tipi kırıklarda alınmaktadır. ${ }^{[13,14]}$ Özellikle ameliyat öncesi iki günden fazla hastanede yatış ve yetersiz kırık stabilizasyonu ameliyat sonrası mortaliteyi arttırmaktadır. ${ }^{[13]}$ B 2 kırıkların tedavisinde komponent revize edilmelidir. Sonuç olarak periprostetik kalça kırıklarının tedavisini yapacak ortopedistin, hem artroplasti cerrahisi hem de travma

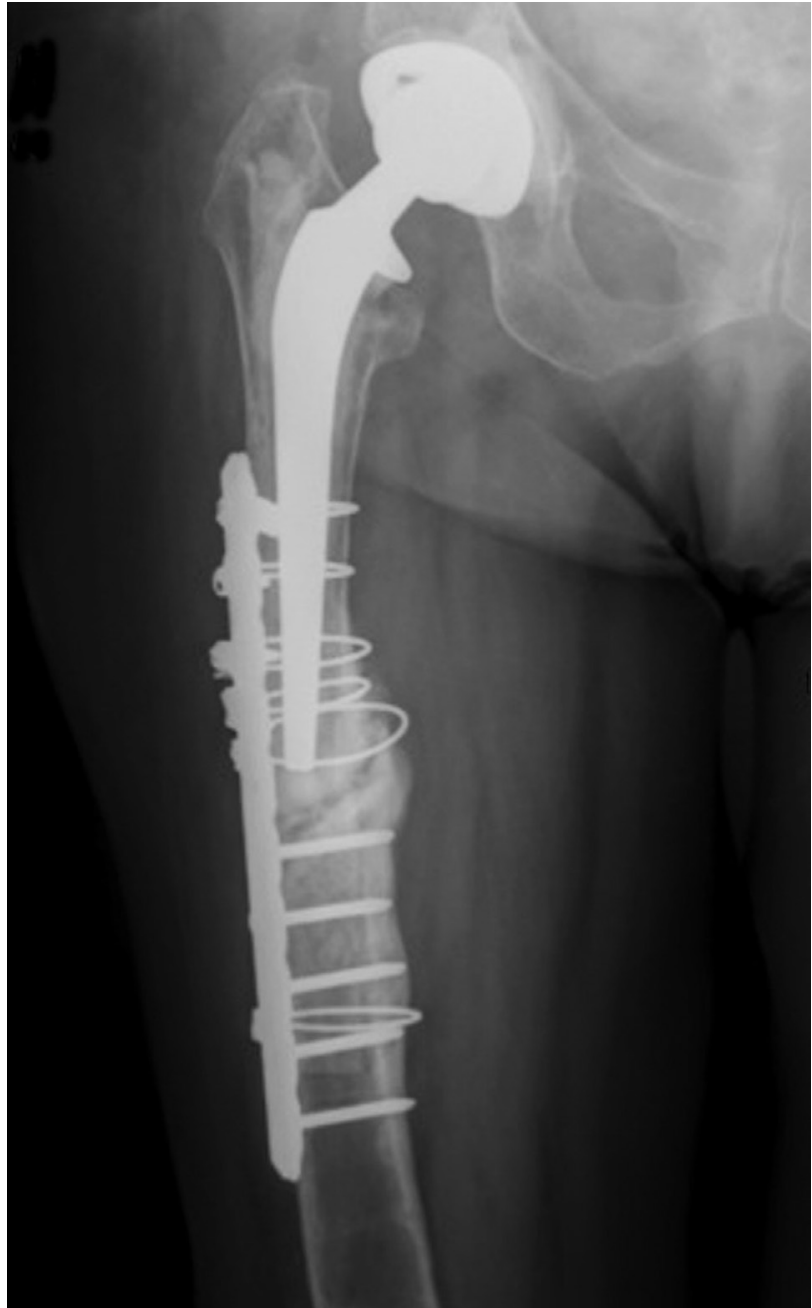

Şekil 13. Kablo-kilitli vida plak ve yapısal allogreft kombinasyonuyla kırığın tespiti.

cerrahisi bilgisi, becerisi ve deneyimine sahip olması gereklidir.

\section{HETEROTOPIK OSSIFIKASYON}

TKP sonrası heterotopik ossifikasyon (HO) çok sık görülür. ${ }^{[15,16]}$ Ancak bu kadar sık görülmesine rağmen çok nadiren şikayete neden olur. HO ile başvurma nedenleri genellikle ağrı, batma, atlama, sıkışma, instabilite ve kalça ekleminde hareket kısıtlılığıdır (Şekil 14). Erkek cinsiyet, entezopati varlığı, ankilozan spondilit veya hipertrofik artrit varlığı, beyin hasarı varlığı, diffüz idiopatik skeletal hiperostoz varlığı, post-travmatik osteoartitit, kalça ankilozunun proteze dönüştürülmesi, anterior ve lateral kalça yaklaşımı, geniş adale sıyrılması ve ameliyat öncesi $\mathrm{HO}$ varlığı, ameliyat sonrası $\mathrm{HO}$ gelişimi için risk faktörleridir. ${ }^{[16,17]} \mathrm{HO}$ 'nun sınıflandırılmasında Brooker sınıflaması kullanılır (Tablo 3). ${ }^{[18]}$ 


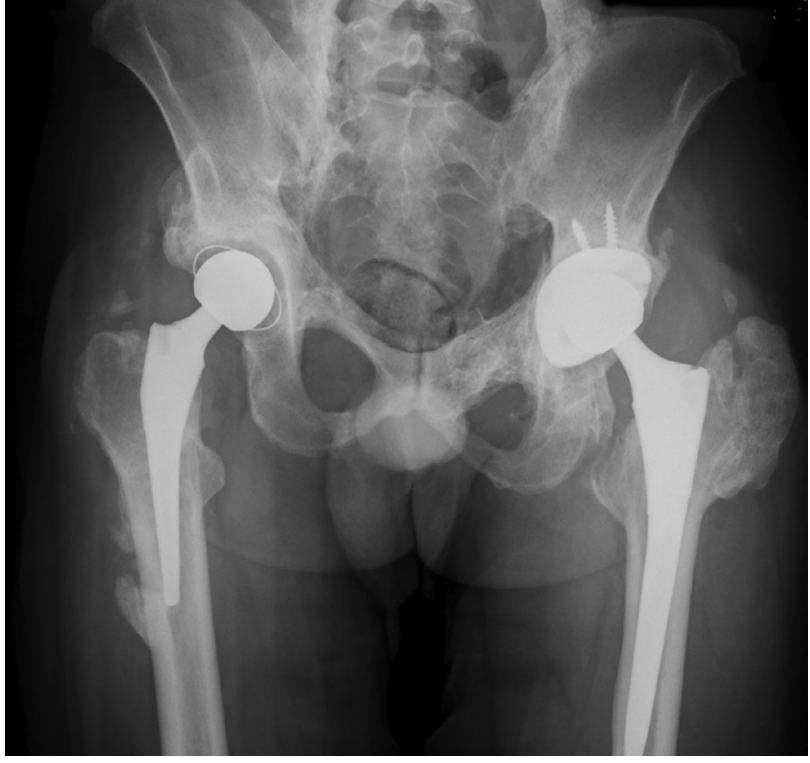

Şekil 14. Her iki kalçada yaygın heterotopik ossifikasyon.

$\mathrm{HO}$ genel olarak sadece ciddi hareket kısıtlılığı, sıkışma ve instabilite yaratması dahilinde ameliyat edilir. Genel olarak Tip 1 ve 2 herhangi bir şikayet yaratmaz iken, Tip 3 ve 4 eksizyon için uygun adaylardır. [19] Cerrahi için gerekli olgunlaşma süresi ortalama 1 yıl olup, kemik sintigrafisi ile olgunlaşma zamanı tam olarak tespit edilebilir. HO profilaksisi tedavisinden daha önemlidir. Yüksek riskli hastaların tanınması ve cerrahi esnasında adale hasarlanmasına dikkat edilmesi gereklidir. Bu hastalarda, profilakside ameliyattan sonra 72 saat içinde ya tek doz 7 Gy veya $5 \mathrm{kez}$ 2 Gy doz ile radyoterapi uygulaması kullanılır. ${ }^{[20,21]}$ Çimentosuz femoral komponent kullanılan hastalarda, radyoterapi esnasında femoral komponentin radyasyon geçirmeyen bir madde ile korunması gereklidir. Bu sayede komponent-kemik kilitlenmesini sağlayan kemik-implant bağlantısının oluşumu engellenmemiş olur. Ayrıca hastalarda radyoterapi sonrası gelişebilecek olan trokanterik bursite karşı hazırlıklı olmak gerekebilir.

$\mathrm{HO}$ için profilaksi ve medikal tedavide günde 75 $\mathrm{mg}$ indometazin tablet 6-8 hafta, ibuprofen ve asetil salisik asit kullanılabilir. ${ }^{[21-23]}$ Son yıllarda plastik drape kullanımının $\mathrm{HO}$ oluşumunu azalttığı bulunmuş olup, piyasaya yeni girecek olan kemik morfogenetik protein (BMP) inhibitörleri (Noggin), BMP Tip 1 reseptör inhibitörleri, çekirdek retinoik asit reseptör gamma agonistleri (RAR-gamma) ve serbest radikal temizleyicilerinin profilaksi ve tedavide yeri olacağı belirtilmektedir. ${ }^{[24,25]}$

\section{IMPLANT BAŞARISIZLIĞı}

TKP ameliyatı sonrası implant başarısızlığı revizyona en sık neden olan faktördür. ${ }^{[26]}$ Bu faktör genel olarak üç ana nedene bağlı oluşur. Koyulan implantın fizikselkimyasal-biyolojik-immünolojik üretim özellikleri, olguya göre seçilmiş olan implantın özellikleri, şekli ve uygulama tekniği, son olarak ülkenin kendi şartlarına göre uyguladığı sağlık şartları ve alım-ödeme koşullarıdır. İmplant başarısızlığının en sık görülme nedeni bu üç nedenin değişik ölçülerde kombinasyonlarıdır. illk neden bu bölümde detaylı olarak anlatılacak olup, genel olarak uygulanan implantın yapım hataları ile ilgili bilgi verilecektir. İkinci neden genellikle biz ortopedistin en sık yaptığı hata olan "yanlış hasta-yanlış endikasyonyanlış protez-yanlış cerrah-yanlış ameliyat" beşlemesidir. Bu en sık revizyona neden olan erken gevşeme, uygun olmayan protez seçimi, hatalı ölçüde protez seçimi, komponent malpozisyonu, instabilite ve cerrahi teknik hataları kapsar. Üçüncü neden ise hem ülkenin imal veya ithal edebildiği hem de sağlık sisteminin karşıladığı implantların menşei, kalitesi ve maliyeti nedeniyledir.

Kullanılan implantın özellikleri başarısızlık üzerinde doğrudan etkilidir. Tüm doğruların yapılmasına rağmen protez enfeksiyonu gibi durumlarda ameliyat sonrası "erken tam başarısızlık" kaçınılmazdır. Ülkemizde de son yıllarda bir kez gördüğümüz ama özellikle Amerika, İngiltere ve İskandinav ülkelerinde daha sık görülen, yeni piyasaya sürülmüş olan bir implantın bir süre sonra implanta bağlı değişik nedenlerle geri toplatıldığını biliyoruz. ${ }^{[27,28]} \mathrm{Bu}$ konuda, ortopedide olan ilk örneklerden biri teflondur. Teflon mükemmel in-vitro eklemleşme özelliklere sahip bir madde iken, in-vivo kullanıldığında aşıı immün reaksiyona neden olduğu için erken revizyonlar nedeniyle piyasadan

Tablo 3. Brooker heterotopik ossifikasyon sınıflandırması. ${ }^{[18]}$

\begin{tabular}{ll}
\hline Tip 1 & Yumuşak dokuda kemik adacıkları varlığı. \\
Tip 2 & Pelviste ve femur proksimalinde yeni oluşan kemikler arasında en az $1 \mathrm{~cm}$ mesafe. \\
Tip 3 & Pelviste ve femur proksimalinde yeni oluşan kemikler arasında $1 \mathrm{~cm}$ 'den az mesafe. \\
Tip 4 & Pelvis ve femur proksimali arasında kemik köprüsü varlığı (Ankiloz).
\end{tabular}




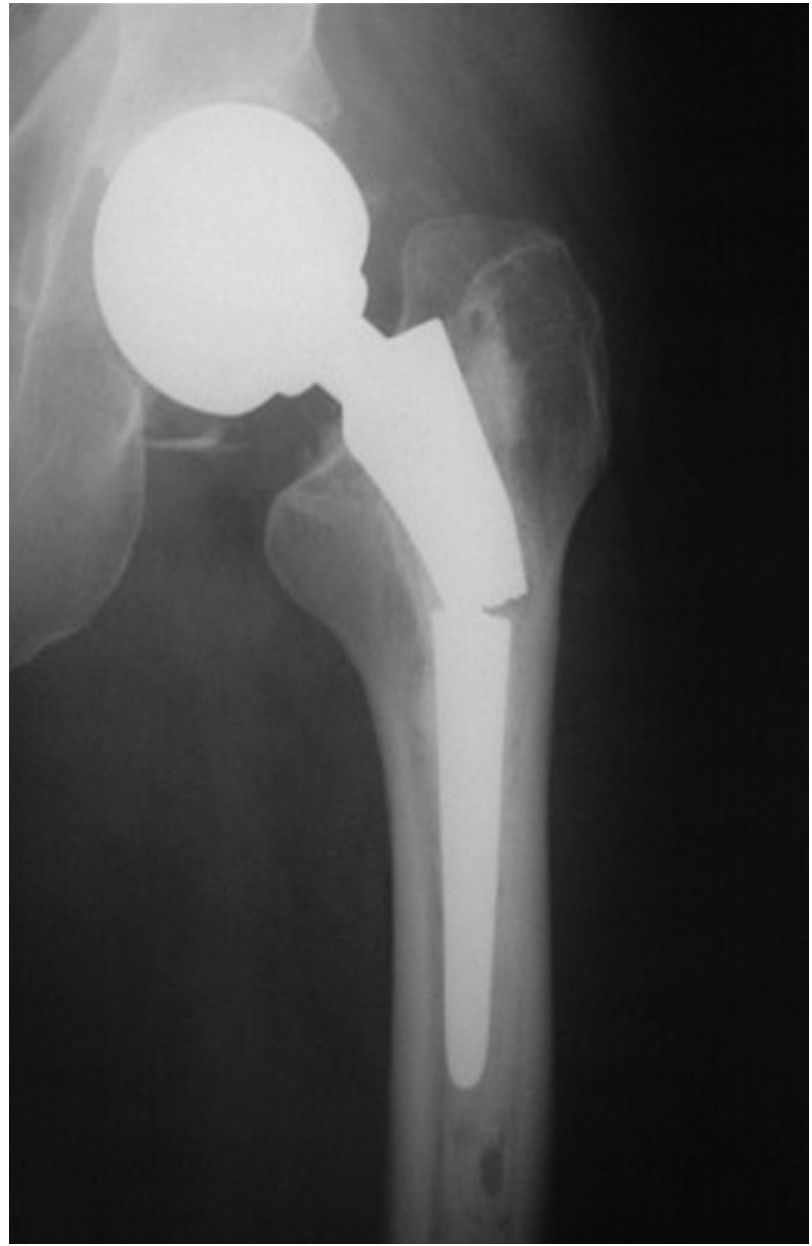

Şekil 15. Metal yorgunluğuna bağlı kırılmış femoral komponent.

kaldırılmıştır. ${ }^{[29]}$ Paslanmaz çelik çimentolu femoral komponentler de bu sefer metal yorgunluğuna bağlı erken kırılmaya neden oldukları için piyasadan kaldırılmıştır. Son yıllarda daha sık kullanılmaya başlanan modüler protezlerin bağlantı kısımlarında ve displazik femurlarda kullanılan çok ince femoral komponentler dışında femoral ve asetabuler komponent kırılmaları çok nadir görülmektedir (Şekil 15). 1990'lardan sonra implanta bağı başarısızlıklar genel olarak eklemleşme yüzeylerine, alerjik yanıta ve kaplama yüzeylerine bağlı olarak görülmektedir.

Genellikle uygun yapılmış bir TKP ameliyatının ömrünü enfeksiyon dışında eklemleşme yüzeyi belirler. Eklemleşme yüzeyinin ömrünün belirlenmesinde ise uygun cerrahi teknik dışında iki önemli belirleyici vardır: Kullanılan maddelerin üretim, sterilizasyon ve saklama koşulları ile seçilen eklemleşme kombinasyonları. 1990'lardan itibaren ultra yüksek molekül ağırlıklı polietilen (UHMWPE) ve kobalt-krom ikilisi eklemleşmede en sık kullanılan maddeler olmasına karşın, hasta takipleri ve yapılan araştırmalarla erken çatlak oluşumu ve delaminasyon nedeniyle artmış erken gevşemeler tespit edilmiştir. Bunun nedeninin ise oksidasyon olduğu ileri sürülmüştür. Bundan dolayı artık günümüzde sterilizasyon inert ortamlarda yapılarak hem oksidasyonun engellenmesi hem de çapraz bağlanmanın artışı sağlanmaktadır. Bu güçlendirme işlemi ile konvansiyonel UHMWPE'in ara parça içine baş penetrasyon oranı yıllık 0,11 mm iken çapraz bağlı polietilende (XLPE) bu oran 0,07 mm'dir. ${ }^{[30]}$ Her ne kadar XLPE ile PE'in aşınma sorunu azalmış olsa da, bu sefer PE'in kırılganlık sorunu ortaya çıkmış olup, görülen erken implant başarısızlığının nedeninin periferik PE kırıklarının olduğu ileri sürülmüştür. ${ }^{[31]}$ Günümüzde yapılan çalışmalar ile PE içine E vitamini eklenmesi, radyasyon ile sterilizasyon sonrası yeniden eritme ve değişik sterilizasyon metodları ile hem PE'in kırılganlığını arttırmadan aşınmasını azaltmak, hem çapraz bağlanmayı arttırmak, hem de in-vivo oksidasyonun ana nedeni olarak vücuttaki lipit prekürsörlerinin PE'e bağlanmasını azaltmak amaçlanmaktadır. ${ }^{[32]}$

Metal-metal eklem yüzeyleri ilk kullanılmaya başlandığında hem sert hem de aşınmaya aşırı dayanıklı oldukları için çok popüler olmuşlardı. Özellikle hem büyük baş kullanma seçeneğinin olması hem de başlarda popüler sporcularda kullanılması bu eklem yüzeyini hastalar ve ortopedistlerce sık aranır hale getirmiştir. Ancak uygulamalar arttıkça bu eklem yüzeyinin de sorunsuz olmadığı görülmüştür. Yüksek maliyetleri bir tarafa bırakıldığında bile, kanda yüksek konsantrasyonlarda artmış metal iyonları, protez çevresi metallozis gelişimi, aseptik lenfositik vaskülit (ALVAL) ve yalancı tümör oluşumları nedeniyle ilk başlardaki popülaritesini kaybetmeye başlamıştır. ${ }^{[3,34]}$

Seramik-seramik eklem yüzeyleri ilk kullanılmaya başlandığı zamanlarda düşük aşınma özelliklerine rağmen, PE ile kombine kullanılsalar dahi erken kırıklardan dolayı sıkça başarısızlığa uğruyorlardı. ${ }^{[35]}$ Ancak yıllar içinde teknolojik ilerlemeler ile seramik-seramik eklemleşmede ve kombinasyonlarında kırılma ile ilgili sorunlar çok azaldı. Zamanla delta seramik, büyük baş kullanımı, metal-seramik kombinasyonları seçenekleri piyasaya sunuldu. Günümüzde, seramik eklemleşmede iki adet ameliyat sonrası artsorun öne çıkmaktadır. Bunlardan ilki hastalarda ciddi bir ameliyat sonrası soruna neden olan gıcırdama sesi, diğeri ise seramiğe has yeni bir aşınma tipi olan şeritsel aşınmadır (stripe wear). Gıcırdama sesinin ve şeritsel aşınmanın en sık nedeninin ise kullanılan seramiğin fiziksel özelliklerinden çok, uygulama hataları olduğu bulunmuştur. ${ }^{[36]}$ Uygun açılarda konmuş asetabuler ve femoral komponentlerde bu iki soruna çok nadir rastlanılır. Yıllar 
içinde hem seramik komponentlerin maliyetlerinin düşmesi hem büyük baş seçeneklerinin artması hem de uygulama hatalarının azalması ile bu kombinasyonun daha sık kullanılacağı düşünülmektedir.

İmplantlar üzerine kullanılan kaplamalar özellikle çimentosuz protezler açısından bir çığır açmıştır. Bu sayede tüm dünyada en sık kullanılan çimentolu protezlerin yerini almışlardır. Bu kaplamalar plazma spreyleme, kumlama, boncuklama ve tel örgülemedir. Yıllar içinde hem teknolojinin ilerlemesi hem de denetim sayesinde büyük implant üreticilerinde genellikle bu soruna nadiren ve sporadik olarak rastlanır. Ancak karşılaşıldığı zaman genel olarak çok erken başarısızlık ve revizyonla sonuçlanır. Erken kaplama bozulması ile karşılaşmamak için kullanılacak implantın değişik denetim kuruluşlarında yapılmış kalite kontrol onayının incelenmesi ve buna göre uygulanması gereklidir.

Koyulmuş olan implantın erken başarısızlığının bir nedeni de hastaya ait faktörlerdir. Aşırı kullanım, sık travma, aşırı yüklenme ve sigara/ilaç kullanımı dışında; son yıllarda daha sık araştırılan hastaya spesifik genetik ve biyolojik özellikler de erken gevşeme ve ağrıda rol oynar. ${ }^{[37,38]}$ Gelecek yıllarda bu özelliklerin daha iyi bilinmesiyle, ameliyat öncesi uyumluluk testleri yapılarak bu artsorunun önüne geçilebilir.

\section{NÖROVASKÜLER KOMPLIKASYONLAR}

Proksimal femur veya asetabulum kırı̆ıı sonrası uygulamalar haricinde, TKP genel olarak elektif bir ameliyattır. Ameliyat öncesi yürüyerek gelen bir hastanın ameliyat içi ölümü veya nörolojik olarak hasarlanması hem cerrah hem de hasta ve yakınları tarafından çok üzücü bir tablodur. Her ne kadar anesteziye veya hastanın yatış pozisyonuna bağlı mortal veya morbid artsorunlar da görülebilse de, genel olarak bu konuda en büyük sorumluluk ve hata ameliyat yapan cerrahi ekibe aittir. [39]

Vasküler artsorunlar olarak en sık akut veya gecikmiş kanama, arteriovenöz fistül veya yalancı anevrizma oluşumu ve arteriyel tıkanma sayılabilir. ${ }^{[39]}$ Sıklıkla majör vasküler yaralanmaya uğrayan damarlar ise eksternal iliak arter ve ven, femoral arter ve ven, obturator arter, superior gluteal arter ve ven ve corona mortistir. Görülme sıklığı \%0,1-1 iken bu hastaların yaklaşık yarısında eksternal iliak arter hasarlanır. ${ }^{[40]}$ Majör damar yaralanması olan hastaların yaklaşık \%7-10'u ölür. Hasarlanma nedeni direkt (bistüri, matkap ucu gibi delici-kesici bir aletle veya ekartör gibi ezici bir aletle) veya indirekt (uzun süre aterosklerotik damarların bükülü kalması) olarak gelişir. Bu üzücü artsorunun gelişmesini önlemek için damarların anatomik yerlerinin iyi bilinip komponent ve özellikle asetabuler vidaları dikkatli koymak, gereksiz ekartör yeri değişikliği yapmamak, asetabulum oyulurken internal tabulayı geçmemek ve özellikle aterosklerotik hastalarda bacağı uzun süre kıvrık pozisyonda tutmamaya özen göstermek gerekir. ${ }^{[1]]}$ Wasielewski, asetabulumu bir daire olarak dört eşit kadrana ayırmıştır. ${ }^{[42]}$ Asetabulumun orta noktası merkez olacak şekildedir. İlk olarak anterior superior iliak çıkıntıdan asetabuler fossaya bir çizgi çizilir ve böylece asetabulum ikiye ayrılır. íkinci çizgi ise asetabulum orta noktasından bu hatta bir dik çizilmesi ile elde edilir. Bu sayede önde iki arkada iki çeyrek daire elde edilir. Genel olarak posterior-superior ve posterior-inferior çeyrekler vida konması için daha güvenilirdir. ${ }^{[42]}$ Eğer yüksek kalça merkezli bir asetabulum yapılmış ise, bu bölgelerin sadece periferik bölümlerine vida konması daha güvenli bulunmuştur. ${ }^{[43]}$ Ancak unutulmaması gereken üç ana sorun daha vardır. İlk olarak tüm hastaların damar anatomisi ve yerleri birbirinin aynısı değildir, ikinci olarak özellikle yan yatmış bir hastada ameliyat masasına tam sabitleme yapılmamış ve eğilmiş ise asetabulumun konfigürasyonunu yere göre yapmak hatalı olacaktır, son olarak özellikle Crowe Tip 4 kalçalarda anatomi tamamen bozulmuş olabilecektir. [44] Böyle bir majör damar yaralanması olduğu zaman tedavide yapılacak en büyük hata paniğe kapılmaktır. Kanayan yere baskı uygulama ve gazlı bezle doldurma ilk yapılması gereken durumdur. Anestezi doktoru bu durumdan haberdar edilir ve tansiyonun düzenlenmesi ve ekstra kan hazırlanması sağlanır. Kanama güçlü ve çok miktarda ise, damar cerrahisi konsültasyonu istenir. Eğer kompresyona rağmen kanama hiç durmuyorsa, hasta hemen sırt üstü çevrilerek ilioinguinal insizyonla iliak arter ve/veya ven geçici olarak bağlanır. Eğer corona mortis yaralanmış ise acil genel cerrahi konsültasyonu istenir. Bu artsoruna yakın hasta grubu, yüksekte kalça çıkığı olan, zayıf, adalesi az, yaşlı, hipertansif ve aterosklerotik damar hastalığı olan hastalardır. Damar yaralanması gelişmesi için risk faktörleri ise daha önce fibrozise zemin hazırlayacak kalça ameliyatı geçirmiş olma, revizyon ameliyatları, aşırı keskin asetabuler oyucu varlığı, gereksiz uzun asetabuler vida koyma, kotiloplasti veya asetabuler kafes koyma zorunluluğudur (Şekil 16, 17).

Sinir yaralanması ise primer TKP ameliyatlarında $\% 0,1-1,3$ arasında görülürken, revizyon ameliyatlarında bu oran \%7,5'e dek çıkar. ${ }^{[39,45]}$ Bu yaralanma en sık açılım ve ekartasyon esnasında olurken, sonra sırasıyla kalça redüksiyonu ve kapama sırasında da oluşabilir. Sinir yaralanmaları gerilme, ezilme, kesilme veya iskemi ile olabilir. Sinir yaralanmaların sınırlandırmasında Sunderland sınıflandırması kullanılır (Tablo 4). ${ }^{[46]}$

Hasarlanan sinirler ve hasar oluşma nedenleri sıralanacak olursa, ani bacak boyu uzatılması veya 


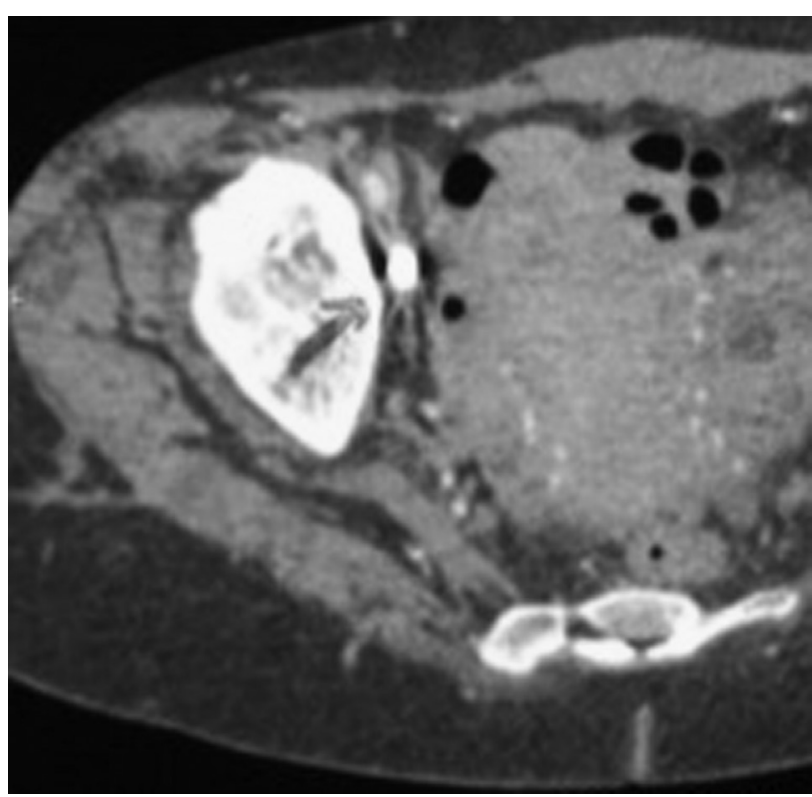

Şekil 16. Hatalı konmuş asetabuler vidanın iliak damarlarla komşuluğu.

zorlamalı redüksiyon esnasında siyatik sinirin peroneal ayrımında veya femoral sinirde hasarlanma, posterior yaklaşımla siyatik sinirde hasarlanma, lateral yaklaşımla süperior gluteal sinirde hasarlanma, anterolateral yaklaşımla femoral sinirde hasarlanma, gluteal hematom oluşumu ile siyatik sinirde hasarlanma ve çimentolu asetabuler komponent uygulama esnasında obturator sinirde hasarlanma oluşabilir. ${ }^{\left[{ }^{[9]}\right.}$ Genel olarak bacak boyunun 4-6 cm'den fazla akut olarak uzatılmasının sinir hasarlanmasına yol açacağı öngörülse de, bizce bacak boyunun uzatılmasında sinir hasarını engellemek için genel uzatma miktarından çok hem ameliyat öncesi siyatik sinirin boyuna bakılıp siniri \%6'sından fazla uzatmamak, hem de ameliyat içi siyatik sinirin gerginliğine bakılarak uzatma miktarına karar vermek daha uygun bir yaklaşım olacaktır. [39,47] Eğer sinir hasarı oluşmuş ise bu hasarın geliştiği zaman tedavide önemlidir. Eğer ameliyat sonrası

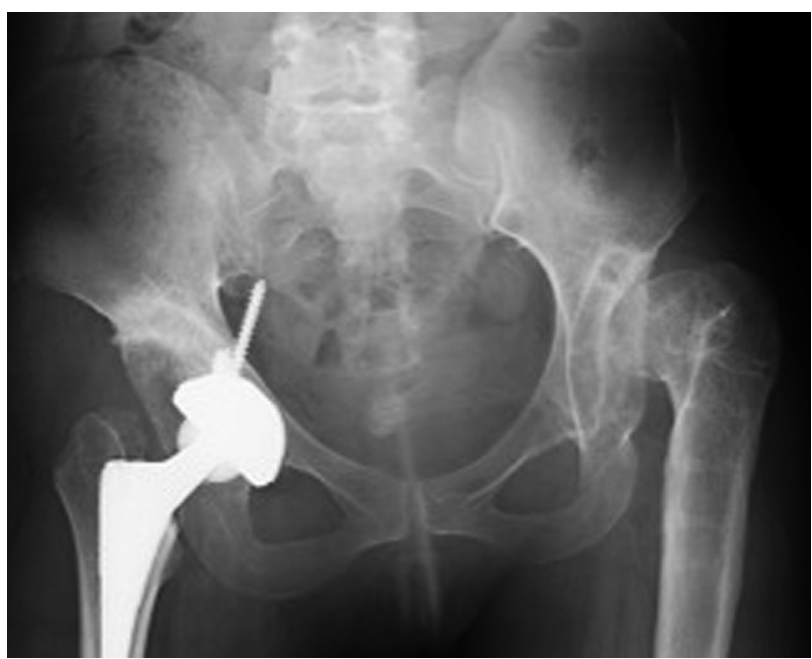

Şekil 17. Gereksiz uzun konmuş asetabuler vidaya bağlı gelişen nörovasküler artsorun.

herhangi bir sorun yokken, günler içinde başlayıp ilerleyen bir nörolojik defisit var ise, bu genellikle ya gluteal hematom veya pseudoanevrizma gelişimine işaret eder ki, tedavisi acil dekompresyon ve/veya tamirdir. Eğer hasta uyandığından itibaren nörolojik defisit var ise; sinirin kesildiği veya kablo ile sıkıştığı düşünülüyor ise acil eksplorasyon, eğer böyle bir düşünce yok ise destek tedavisi ve atelleme (AFO, KAFO) ile takip uygundur. ${ }^{[39,48]}$ Takip esnasında ameliyattan sonra 1. ay, 3. ay ve 1. yıl EMG ile sinir rejenerasyonu değerlendirilir ve herhangi bir düzelme yok ise, 1. yıldan sonra cerrahi müdahale yapmak uygundur. Cerrahi dışı prognoz çok değişken olup, yaralanma tipi ve sinire göre değişkenlik gösterir. Genel olarak \%20-36 arası tam iyileşme gözlenirken, bu süre peroneal palside 14 ay, siyatik palside 5 yıla dek sürebilir. ${ }^{[48]}$ iyileşme herhangi bir seviyede durabilir veya kronik kozalji ile de sonuçlanabilir. Eğer takip esnasında yeterli bekleme süresine rağmen herhangi bir gelişme yok ise, tibialis posterior veya peroneus longus tendonlarının kuneiform üzerine transferi ile ayak dorsifleksiyonu

Tablo 4. Sunderland periferik sinir yaralanması sınıflandırması. ${ }^{[46]}$

\begin{tabular}{lll}
\hline Derece & Tip & Tanımlama \\
\hline $\mathbf{1}$ & Nöropraksi & Aksonal iletimin kaybı \\
$\mathbf{2}$ & Aksonotimezis & Sağlam endonöriyumla birlikte devamlılığın kaybı \\
$\mathbf{3}$ & Aksonotimezis (3. Hafif) & Sağlam perinöriyumla birlikte sinir liflerinin kesilmesi \\
& Nörotimezis (3. Ciddi) & \\
$\mathbf{4}$ & Nörotimezis & Perinöriyum ve fasiküler devamlılığın kaybı \\
$\mathbf{5}$ & Nörotimezis & Tüm sinir kökünün devamlılığının kaybı
\end{tabular}




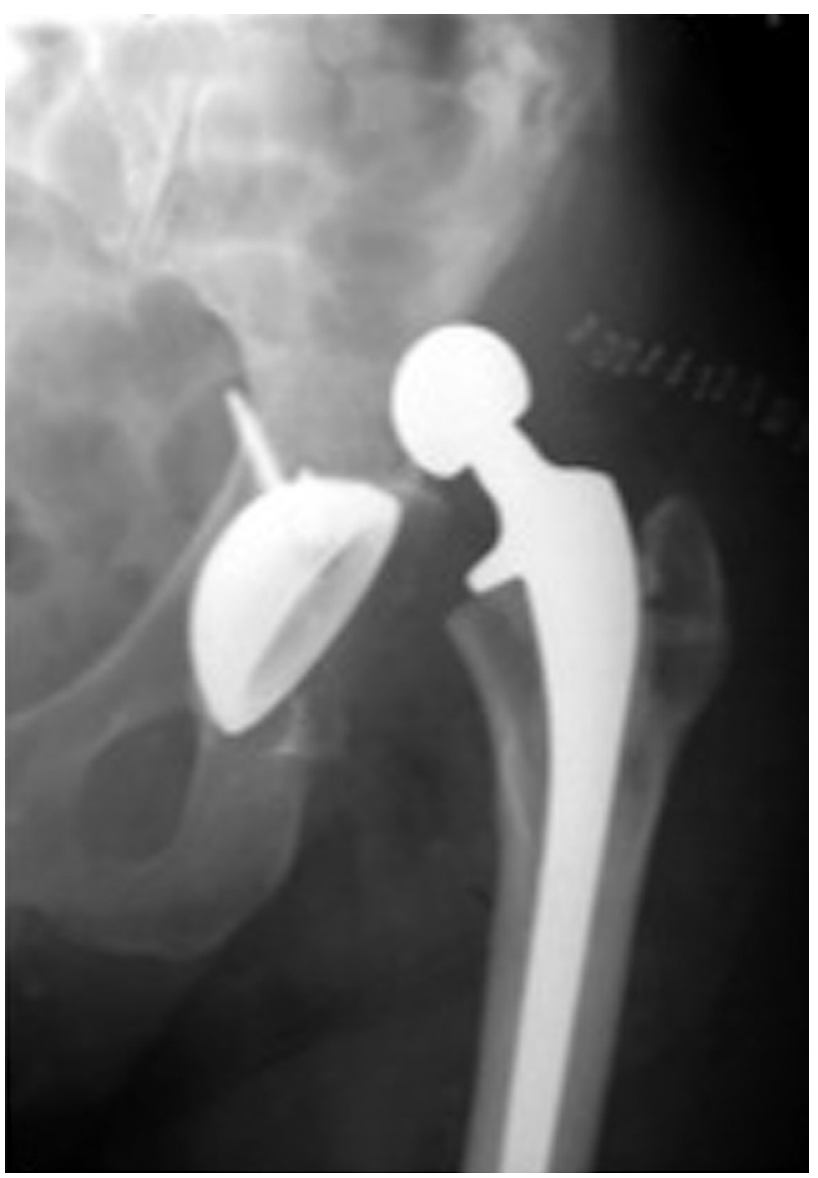

Şekil 18. Ameliyat sonrası erken çıkık.

sağlanabilir. ${ }^{[99]}$ Aynı seans içinde istenirse siyatik sinir eksplore edilebilir. Sinir yaralanması artsorunu için riskli hasta grubu ise, adalesi zayıf, ince, çok kısa boylu ve özellikle Crowe Tip 3-4 hastalar, önceden fibrozis gelişimine neden olacak kalça ameliyatı olmuş hastalar, kanamaya meyilli hastalar, revizyon ameliyatı geçirecek hastalardır.

\section{INSTABILITE}

TKP sonrası çıkı, bildirilen en sık artsorunlardan biridir. Primer TKP sonrası \%0,1-10, revizyon sonrası \%27 oranında görülebilir. ${ }^{[50,51]}$ Çıkık genel olarak ameliyattan sonra ilk 4-6 haftada görülür. Bundan sonra görülen çıkıklar genellikle ya travmaya bağlı ya da gevşeme sonrası oluşur.

Çıkığın nedenleri genellikle hastaya, ameliyat öncesi tanı ve geçirilmiş tedavilere, konmuş implanta, yapılan cerrahi tekniğe, komponent yerleştirilme şekline, eklem dışı sıkışmaya ve cerrahın tecrübesine bağlı olarak gruplandırılabilir (Şekil 18).
Çıkık genel olarak kadınlarda daha sık görülür. ${ }^{[50]}$ Bunun nedeni olarak, hem displaziye ikincil TKP ameliyatının kadınlarda daha sık yapılması, hem de erkeklere göre yumuşak dokularının daha esnek olmasıdır. Yaş ile birlikte çıkık artar. Bunun nedeni olarak, hastalarda hem adalelerde zayıflama hem de nörokognitif bozuklukların sıklığı sorumlu tutulmaktadır. ${ }^{[52]}$ Genellikle ASA 3 ve 4 hastalarda çıkık daha sık görülür. ${ }^{[53]}$

TKP ameliyatını olma nedeni, proksimal femurasetabulum kırığı, gelişimsel kalça displazisi, avasküler nekroz veya romatoid artrit ise, bu hastalarda instabiliteye diğer hastalardan daha sık rastlanır. ${ }^{[33]}$ Daha önce kalça cerrahisi geçirme de, instabilitede risk faktörü olarak rol oynar.

Adale distrofisi, serebral palsi, epilepsi, psikoz, Alzheimer ve Parkinson hastalığı gibi hastalıklar ile, serebrovasküler olay (SVO) geçirme, kronik alkolizm ve uyuşturucu kullanımı öyküsü olan hastalarda, adale koordinasyonu ve denge bozukluğu veya zaafiyetine bağlı çıkık riski artar. ${ }^{[54,55]}$

Kalçanın hareketleri esnasında femur boynu ile asetabuler komponentin (veya ara parçanın) kenarı arasında oluşan temas, kalçada sıkışma yaratır. Bu sıkışma, bir kaldıraç görevi görerek kalçayı çıkartır. Bu sıkışmanın engellenmesindeki seçeneklerden biri, boyun kalınlığı aynı kalsa da, başı büyütmektir. Buna baş boyun ofsetinin arttırılması denir. Bu sayede boyun aynı kalınlıkta kalmak şartıyla daha büyük baş kullanılırsa, daha yüksek hareket açıkıklarında bile, kalçada sıkışma oluşmaz. Ancak büyük baş kullanılsa bile, yakalıklı femoral baş kullanımı veya açılı asetabuler ara parça kullanımı ile kalçada sıkışma görülmesi olasıdır.

Çıkık, ameliyat içi kalçaya yaklaşım ile doğrudan iliş̧ilidir. En sık uygulanan posterior yaklaşım ile posterior kapsül ve dış rotatorların kesilmesi \%90'a yakın sıklıkta görülen posterior kalça çıkığına zemin hazırlamış olur. ${ }^{[56]}$ Posterior yaklaşımla \%3,2, direkt lateral yaklaşımla \%0,6, direkt anterior yaklaşımla \%0,6, anterolateral yaklaşımla $\% 2,2$ oranında ameliyat sonrası çıkık bildirilmiştir. ${ }^{[27]}$ Posterior yaklaşıma bağlı oluşan kalça çıkığı sıklığı, kemiğe sabitlenerek yapılan kapsül ve dış rotator tamiri ile belirgin şekilde düşmektedir. ${ }^{[53]}$

Komponent malpozisyonu da ameliyat sonrası çıkıkla doğrudan ilişkilidir. Asetabuler komponentle başlarsak, aşırı öne dönük (antevert) bir komponent ile öne, arkaya dönük (retrovert) bir komponent ile arkaya kalça çıkığı geliş̧ebilir (Şekil 19). Dik konmuş (aşırı inklinasyon sonucu) kalça adduksiyonu ile lateral çıkık olurken, yatay konmuş bir komponentte ise adduksiyonda süperiorda kalça sıkışması gelişecektir. TKP ameliyatının yapılmasına başlandıktan sonra yıllar içinde asetabulumun pozisyonlandırılması ile ilgili çok 


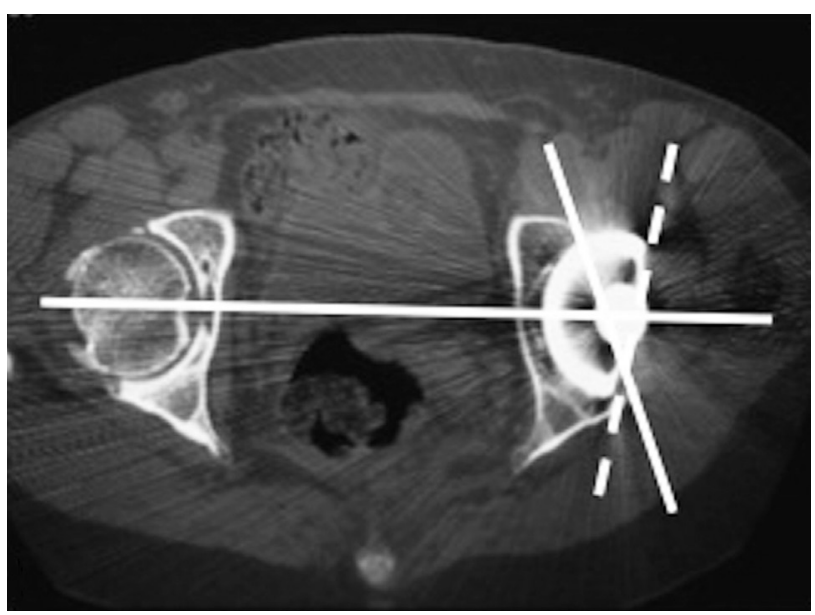

Şekil 19. Asetabuler komponentte retroversiyona bağlı instabilite.

sayıda tartışma olsa da, genel olarak halen $40^{\circ} \pm 10^{\circ}$ inklinasyon ve $15^{\circ} \pm 10^{\circ}$ anteversiyon altın standarttır. [57] Günümüzde kullanılan navigasyon teknolojileri veya robotik cerrahi seçenekleri ile bu konumlandırma daha kolay sağlanmaktadır. Asetabuler komponentin medialize edilmesi veya yükseğe konması ise hem yumuşak doku gerginliğine hem de kalça abduktor kol gevşekliğine yol açabileceğinden, instabiliteye neden olabilir.

Femoral komponentin antevert veya retrovert pozisyonunda konumlanması da kalça instabilitesinde etkilidir. Versiyon dışında varus veya valgus malpozisyonu erken dönemde stabilite ile ilgili sorun yaratmazken, geç dönemde aseptik gevşeme ve bununla birlikte instabilitenin de dahil olduğu bir çok soruna yol açacaktır. ${ }^{[33]}$ Femoral komponentin ofset yetersizliği veya kısa boy ayarlaması da hem kalça yumuşak doku gevşekliği hem de abduktor kol zafiyetine bağlı olarak instabiliteye yol açacaktır. ${ }^{[58]}$

Eklem dışı sıkışma genel olarak ya komponentlerin kemik yüzeylere teması ile veya kemik yüzeylerin birbirine teması ile oluşur. ${ }^{[58]} \mathrm{Bu}$ temasın ana nedeni kalça eklem mesafesinin veya ofsetinin uygun ayarlanmamasıdır. Bu ayarlamanın uygun olduğu durumlarda ise, özellikle asetabulum ön dudağında bulunan osteofitlerin kalçanın iç rotasyonunda femura teması ile arkaya çıkık gelişebilir. Bunun engellenmesi için deneme aşamasında asetabulum ön dudağını osteotomi ile temizlemek, eğer yetmiyor ise trokanter majörün üzerindeki osteofitleri de temizlemek gerekir. Bunun dışında trokanter minör ile iskium kolu arasındaki temasa da dikkat edilmelidir. Eklem dışı sıkışmanın geç nedeni ise daha önce anlatılmış olan HO'dur. Ameliyat sonrası gelişen $\mathrm{HO}$, bazı vakalarda eklem dışı sıkışma ve buna bağlı instabiliteye neden olabilir.
Cerrahi deneyim ve yetenek ise tüm yukarda belirtilen nedenlerden çok daha fazla oranda instabiliteden ve onun ameliyat içi önlenmesinden sorumludur. ${ }^{[54]}$

\section{SONUÇ}

Total kalça protezi ameliyatları; ameliyat sonrası kısa sürede ulaşılabilen yüksek hasta memnuniyetine olanak sağlaması ve göreceli olarak kısa ve kolay bir cerrahi işlem olması nedeniyle ülkemizde çok sık yapılmaktadır. Ancak bilinmelidir ki, enfeksiyon ve derin ven trombozu dışında da ameliyat sonrası oluşacak artsorunlar vardır. Mekanik artsorunlar da, ameliyat sonrası hem hasta hem de ameliyatı yapan cerrahı çok etkileyen sorunlardır. Mekanik artsorunların tedavisi, ilk olarak onların oluşmasını engellemeyi, eğer engellenemedi ise tedavisi için müdahale etmeden önce nedeni ve çözüm algoritmalarını iyi öğrenmeyi gerektirir. Enfeksiyon veya derin ven trombozunun aksine, doğru tanı ve doğru tedavi algoritması ile bu artsorunların çok büyük bir kısmı iyi sonuçlanır.

\section{KAYNAKLAR}

1. Scott RD, Turner RH, Leitzes SM, Aufranc OE. Femoral fractures in conjunction with total hip replacement. J Bone Joint Surg Am 1975;57(4):494-501.

2. Peterson CA, Lewallen DG. Periprosthetic fracture of the acetabulum after total hip arthroplasty. J Bone Joint Surg Am 1996;78(8):1206-13.

3. Berry DJ, Lewallen DG, Hanssen AD, Cabanela ME. Pelvic discontinuity in revision total hip arthroplasty. J Bone Joint Surg Am 1999;81(12):1692-702.

4. Meek RM, Garbuz DS, Masri BA, Greidanus NV, Duncan CP. Intraoperative fracture of the femur in revision total hip arthroplasty with a diaphyseal fitting stem. J Bone Joint Surg Am 2004;86-A(3):480-5.

5. Beals RK, Tower SS. Periprosthetic fractures of the femur. An analysis of 93 fractures. Clin Orthop Relat Res 1996;(327):238-46.

6. Letournel E. Fractures of the acetabulum: a study of a series of 75 cases -- Les fractures du cotyle, etude d'une serie de 75 cas. J de Chirurgie 1961;82:47-87. (Translated and substantially abridged). J Orthop Trauma 2006;20(1 Suppl):S15-9.

7. Duncan CP, Masri BA. Fractures of the femur after hip replacement. Instr Course Lect 1995;44:293-304.

8. Masri BA, Meek RM, Duncan CP. Periprosthetic fractures evaluation and treatment. Clin Orthop Relat Res 2004;(420):80-95.

9. Larson JE, Chao EY, Fitzgerald RH. Bypassing femoral cortical defects with cemented intramedullary stems. J Orthop Res 1991;9(3):414-21.

10. Haddad FS, Duncan CP, Berry DJ, Lewallen DG, Gross AE, Chandler HP. Periprosthetic femoral fractures around wellfixed implants: use of cortical onlay allografts with or without a plate. J Bone Joint Surg Am 2002;84-A(6):945-50.

11. Rasouli MR, Porat MD, Hozack WJ, Parvizi J. Proximal femoral replacement and allograft prosthesis composite in the treatment of periprosthetic fractures with significant proximal bone loss. Orthop Surg 2012;4(4):203-10. CrossRef 
12. McLean AL, Patton JT, Moran M. Femoral replacement for salvage of periprosthetic fracture around a total hip replacement. Injury 2012;43(7):1166-9. CrossRef

13. Bhattacharyya T, Chang D, Meigs JB, Estok DM 2nd, Malchau $\mathrm{H}$. Mortality after periprosthetic fracture of the femur. J Bone Joint Surg Am 2007;89(12):2658-62.

14. Golec E, Nowak S, Golec J, Sienkiewicz D, Jurczak P, Zuzek P. Femur periprosthetic fracture complicating revision hip arthroplasty-outcomes of treatment and rehabilitation. Przegl Lek 2008;65(1):8-12.

15. Scott CE, Streit J, Biant LC, Breusch SJ. Periarticular infiltration in total hip replacement: effect on heterotopic ossification, analgesic requirements and outcome. Arch Orthop Trauma Surg 2012;132(5):703-9. CrossRef

16. Pavlou G, Salhab M, Murugesan L, Jallad S, Petsatodis G, West R, Tsiridis E. Risk factors for heterotopic ossification in primary total hip arthroplasty. Hip Int, 2012. 22(1):50-5. CrossRef

17. Koczy B, Stołtny T, Swiderski M, Pyda M, Pajak J, Spindel J, Wawrzynek W, Miszczyk L, Kasperczyk S, Widuchowski J. Heterotopic ossification in patients with hip osteoarthritis below forty years old after total hip replacement. Ortop Traumatol Rehabil 2009;11(5):458-66.

18. Brooker AF, Bowerman JW, Robinson RA, Riley LH Jr. Ectopic ossification following total hip replacement. Incidence and a method of classification. J Bone Joint Surg Am 1973;55(8):1629-32.

19. Iorio R, Healy WL. Heterotopic ossification after hip and knee arthroplasty: risk factors, prevention, and treatment. J Am Acad Orthop Surg 2002;10(6):409-16.

20. Pakos EE, Tsekeris PG, Paschos NK, Pitouli EJ, Motsis EK, Xenakis TA. The role of radiation dose in a combined therapeutic protocol for the prevention of heterotopic ossification after total hip replacement. J BUON 2010;15(1):74-8.

21. Cohn RM, Schwarzkopf R, Jaffe F. Heterotopic ossification after total hip arthroplasty. Am J Orthop (Belle Mead NJ) 2011;40(11):E232-5.

22. Nunley RM, Zhu J, Clohisy JC, Barrack RL. Aspirin decreases heterotopic ossification after hip resurfacing. Clin Orthop Relat Res 2011;469(6):1614-20. CrossRef

23. Spinarelli A, Patella V, Petrera M, Abate A, Pesce V, Patella $S$. Heterotopic ossification after total hip arthroplasty: our experience. Musculoskelet Surg 2011;95(1):1-5. CrossRef

24. Shields JS, Mofidi A, Ward WG, Jinnah RH. Does a plastic drape reduce incidence of heterotopic ossification after hip resurfacing? Clin Orthop Relat Res 2011;469(6):1606-13. CrossRef

25. Pavlou G, Kyrkos M, Tsialogiannis E, Korres N, Tsiridis E. Pharmacological treatment of heterotopic ossification following hip surgery: an update. Expert Opin Pharmacother 2012;13(5):619-22. CrossRef

26. Bozic KJ, Chiu WW, Takemoto SK, Greenbaum JN, Smith TM, Jerabek SA, Berry DJ. The validity of using administrative claims data in total joint arthroplasty outcomes research. J Arthroplasty 2010;25(6 Suppl):58-61. CrossRef

27. Glassmann AH, Lachiewicz PF, Tanzer M, editors. Orthopaedic knowledge update. Hip and knee reconstruction 4. 3rd ed. Rosemont, IL: American Academy of Orthopaedic Surgeons; 2011.

28. Flynn J, ed. Orthopaedic knowledge update 10. Rosemont, PA: American Academy of Orthopaedic Surgeons; 2010.

29. Dupont JA, Charnley J. Low-friction arthroplasty of the hip for the failures of previous operations. J Bone Joint Surg $\mathrm{Br}$ 1972;54(1):77-87.
30. Ayers DC, Hays PL, Drew JM, Eskander MS, Osuch D, Bragdon CR. Two-year radiostereometric analysis evaluation of femoral head penetration in a challenging population of young total hip arthroplasty patients. J Arthroplasty 2009;24(6 Suppl):9-14. CrossRef

31. Schroder DT, Kelly NH, Wright TM, Parks ML. Retrieved highly crosslinked UHMWPE acetabular liners have similar wear damage as conventional UHMWPE. Clin Orthop Relat Res 2011;469(2):387-94. CrossRef

32. Gomez-Barrena E, Puertolas JA, Munuera L, Konttinen YT. Update on UHMWPE research: from the bench to the bedside. Acta Orthop 2008;79(6):832-40. CrossRef

33. Lee RK, Nevelos J, Vigdorchik J, Markel DC. Bearing Surfaces for Hip Arthroplasty- Is Metal-on-metal a Passing Fancy? Surg Technol Int 2012;XXII. pii: sti22/11.

34. Imanishi T, Hasegawa M, Sudo A. Serum metal ion levels after second-generation metal-on-metal total hip arthroplasty. Arch Orthop Trauma Surg 2010;130(12):1447-50. CrossRef

35. Callaway GH, Flynn W, Ranawat CS, Sculco TP. Fracture of the femoral head after ceramic-on-polyethylene total hip arthroplasty. J Arthroplasty 1995;10(6):855-9.

36. Walter WL, Kurtz SM, Esposito C, Hozack W, Holley KG, Garino JP, Tuke MA. Retrieval analysis of squeaking alumina ceramic-on-ceramic bearings. J Bone Joint Surg Br 2011;93(12):1597-601. CrossRef

37. Matharu GS, Revell MP, Pynsent PB, Treacy RB. A review of hip resurfacings revised for unexplained pain. Hip Int 2012;22(6):633-40. CrossRef

38. Mrazek F, Gallo J, Stahelova A, Petrek M. Functional variants of the P2RX7 gene, aseptic osteolysis, and revision of the total hip arthroplasty: a preliminary study. Hum Immunol 2010;71(2):201-5. CrossRef

39. Lewallen DG. Neurovascular injury associated with hip arthroplasty. Instr Course Lect 1998;47:275-83.

40. Parvizi J, Pulido L, Slenker N, Macgibeny M, Purtill JJ, Rothman RH. Vascular injuries after total joint arthroplasty. J Arthroplasty 2008;23(8):1115-21. CrossRef

41. Kawasaki $Y$, Egawa H, Hamada D, Takao S, Nakano S, Yasui $\mathrm{N}$. Location of intrapelvic vessels around the acetabulum assessed by three-dimensional computed tomographic angiography: prevention of vascular-related complications in total hip arthroplasty. J Orthop Sci 2012;17(4):397-406. CrossRef

42. Wasielewski RC, Cooperstein LA, Kruger MP, Rubash HE. Acetabular anatomy and the transacetabular fixation of screws in total hip arthroplasty. J Bone Joint Surg Am 1990;72(4):501-8.

43. Wasielewski RC, Galat DD, Sheridan KC, Rubash HE. Acetabular anatomy and transacetabular screw fixation at the high hip center. Clin Orthop Relat Res 2005;438:171-6.

44. Liu Q, Zhou YX, Xu HJ, Tang J, Guo SJ, Tang QH. Safe zone for transacetabular screw fixation in prosthetic acetabular reconstruction of high developmental dysplasia of the hip. J Bone Joint Surg Am 2009;91(12):2880-5. CrossRef

45. Brown DM, McGinnis WC, Mesghali H. Neurophysiologic intraoperative monitoring during revision total hip arthroplasty. J Bone Joint Surg Am 2002;84-A Suppl 2:56-61.

46. Sunderland S. A classification of peripheral nerve injuries producing loss of function. Brain 1951;74(4):491-516.

47. Zhu ZA, Dai KR, Wang Y, Sun YH, Shi DW, Tang J, Hao $Y Q$, Yan MN. Total hip arthroplasty for Crowe type-IV development dysplasia of hip in adults. Zhonghua Wai Ke Za Zhi 2006;44(20):1403-6. 
48. Farrell CM, Springer BD, Haidukewych GJ, Morrey BF. Motor nerve palsy following primary total hip arthroplasty. J Bone Joint Surg Am 2005;87(12):2619-25.

49. Spiroch P, Cizmár I, Freiwald J, PalcákJ. Restoration of active foot extension following peroneal nerve palsy. Rozhl Chir 2012;91(3):151-7.

50. Kavanagh BF, Ilstrup DM, Fitzgerald RH Jr. Revision total hip arthroplasty. J Bone Joint Surg Am 1985;67(4):517-26.

51. Woo RY, Morrey BF. Dislocations after total hip arthroplasty. J Bone Joint Surg Am 1982;64(9):1295-306.

52. Sanchez-Sotelo J, Berry DJ. Epidemiology of instability after total hip replacement. Orthop Clin North Am 2001;32(4):543-52.

53. Kim YH, Choi Y, Kim JS. Influence of patient-, design-, and surgery-related factors on rate of dislocation after primary cementless total hip arthroplasty. J Arthroplasty 2009;24(8):1258-63. CrossRef
54. Hedlundh $U$, Ahnfelt L, Hybbinette $\mathrm{CH}$, Weckstrom J, Fredin $\mathrm{H}$. Surgical experience related to dislocations after total hip arthroplasty. J Bone Joint Surg Br 1996;78(2):206-9.

55. Woolson ST, Rahimtoola ZO. Risk factors for dislocation during the first 3 months after primary total hip replacement. J Arthroplasty 1999;14(6):662-8.

56. Masonis JL, Bourne RB. Surgical approach, abductor function, and total hip arthroplasty dislocation. Clin Orthop Relat Res 2002;(405):46-53.

57. Lewinnek GE, Lewis JL, Tarr R, Compere CL, Zimmerman JR. Dislocations after total hip-replacement arthroplasties. J Bone Joint Surg Am 1978;60(2):217-20.

58. Soong M, Rubash HE, Macaulay W. Dislocation after total hip arthroplasty. J Am Acad Orthop Surg 2004;12(5):314-21. 